\title{
Profile of the Academic Competency of Chemistry Education Students
}

\author{
Bertha Yonata \\ Chemistry Department, Universitas Negeri Surabaya \\ Surabaya, Indonesia \\ berthayonata@unesa.ac.id \\ Wasis \\ Physic Department \\ Universitas Negeri Surabaya \\ Surabaya, Indonesia
}

\author{
Raden Sulaiman \\ Mathematics Department, Universitas Negeri Surabaya \\ Surabaya, Indonesia
}

Elok Sudibyo

Science Department, Universitas Negeri Surabaya

Surabaya, Indonesia

\author{
Muji Sri Prastiwi \\ Biology Department \\ Universitas Negeri Surabaya \\ Surabaya, Indonesia
}

\begin{abstract}
This article reports the results of a limited trial on the academic competence of students in chemical education. This limited trial also measured the level of student confidence and the truth of chemical concepts from a sample of 24 class 2014 chemistry education students who would and were taking thesis data. Chemical education students are asked to work on 11 chemistry competency questions in multiple choices from with 5 answer choices. After that students are also asked to give reasons and determine the level of confidence in the chosen answer option. From the results of the level of confidence and the truth of the chemical concepts owned by students of chemical education, it can be obtained data about the profile of student misconceptions. A total of 9 students were able to work on the problem as much as 6 or more with the right answer. There are 2 out of 24 students having a misconception rate of more than 50 percent and there are 5 out of 24 students who know the concept.
\end{abstract}

Keywords- profile, competence, confidence, misconception

\section{INTRODUCTION}

The shift in the paradigm of education in the 21 st century presents its own challenges in the world of education, especially for universities that are the candidates for educators. But before prospective teacher students can hold a bachelor's degree in education, students should be trained to be able to deal with the challenges of the 21 st century. There are 4 aspects in the demands of the 21 st century. Humans $21 \mathrm{st}$ Century must be able to think critically and have the will to work hard, they are required to be able to analyze existing problems and are required to have a variety of solutions to the problems faced. Creative and critical thinking skills are the abilities, which can sometimes be used interchangeably definition, they have different constructs because they differentiate in outcome of human behaviors [1].

In facts, if students only do what they told to be done it has impact that students do not have the opportunity to develop their thinking skills [2]. In dealing with the problems faced, 21 st century people are required to be able to cooperate in strong collaboration so that good communication skills are needed. Appropriate strategies will be able to require students to work together and communicate well in terms of asking questions and expressing their opinions in solving problems, so that peer tutoring can occur [3]. So in 21 st century people not only have to achieve hard skills but also soft skills. The international studies assess and compare the knowledge, but also the attitudes of students in different fields and at different stages of their education [4].

As a pre service teacher, students should have sufficient ability to become professional teachers. However, the data shows different things, namely Mathematics and natural sciences teachers whose teacher competency exams above passing grade $(\geq 80)$ were less than $2 \%$. In addition to the capabilities needed in the 21 st century, as chemistry educators, pre service teachers should be able to understand chemical phenomena both at the macroscopic, submicroscopic, and symbolic levels. The inability of students to understand chemical phenomena at this level can cause students to experience ignorance of concepts and even misconceptions.

\section{METHODS}

This test was paper and pencil test with multiple choice type. The test consists of basic chemical concept those are: atomic theory models, acid and base, carbon compound, reaction rate, chemical equilibrium, stoichiometry, and thermodynamics. Each number of questions consists of 5 answer options. 
The reason why the students choose the option was also available to be filled. There were also 5 levels of confidence they could choose. The interconnection of answer and confidence level showed in Table I.

TABLE I MISCONCEPTION PROFILE

\begin{tabular}{|c|c|c|}
\hline Answer & Confidence level & Profile \\
\hline Correct & $>2.5$ & Understand the concept \\
\hline Correct & $<2.5$ & Concept Ignorance \\
\hline Incorrect & $<2.5$ & Concept Ignorance \\
\hline Incorrect & $>2.5$ & Misconception \\
\hline
\end{tabular}

There were 24 students who already enrolled and passed all course except writing theses. The students were also students who already teach in real class for one to two months.

\section{RESULTS AND DISCUSSION}

The data collection was conducted on October 2017 at the mathematics and natural sciences faculty Unesa by using multiple choice problem sets consists of 11 questions of chemistry concepts. The data of students profile showed in Table II.

TABLE II MISCONCEPTION PROFILE OF CHEMISTRY EDUCATION STUDENTS

\begin{tabular}{|r|r|r|r|r|r|r|}
\hline $\begin{array}{c}\text { Stu- } \\
\text { dent }\end{array}$ & \multicolumn{2}{|c|}{ Misconception } & \multicolumn{2}{c|}{$\begin{array}{c}\text { Concept } \\
\text { Ignorance }\end{array}$} & \multicolumn{2}{c|}{$\begin{array}{c}\text { Understand the } \\
\text { concept }\end{array}$} \\
\cline { 2 - 8 } & $\begin{array}{c}\text { Total } \\
\text { number }\end{array}$ & \multicolumn{1}{c}{$\%$} & $\begin{array}{c}\text { Total } \\
\text { number }\end{array}$ & \multicolumn{1}{c}{$\%$} & $\begin{array}{c}\text { Total } \\
\text { number }\end{array}$ & \multicolumn{1}{c|}{$\%$} \\
\hline S1 & 2 & 18.18 & 3 & 27.27 & 6 & 54.54 \\
\hline S2 & 3 & 27.27 & 4 & 36.36 & 4 & 36.36 \\
\hline S3 & 4 & 36.36 & 2 & 18.18 & 5 & 45.45 \\
\hline S4 & 4 & 36.36 & 4 & 36.36 & 3 & 27.27 \\
\hline S5 & 1 & 9.09 & 4 & 36.36 & 6 & 54.54 \\
\hline S6 & 2 & 18.18 & 4 & 36.36 & 5 & 45.45 \\
\hline S7 & 2 & 18.18 & 5 & 45.45 & 4 & 36.36 \\
\hline S8 & 3 & 27.27 & 2 & 18.18 & 6 & 54.54 \\
\hline S9 & 3 & 27.27 & 4 & 36.36 & 4 & 36.36 \\
\hline S10 & 4 & 36.36 & 3 & 27.27 & 4 & 36.36 \\
\hline S11 & 1 & 9.09 & 6 & 54.54 & 4 & 36.36 \\
\hline S12 & 1 & 9.09 & 7 & 63.63 & 3 & 27.27 \\
\hline S13 & 5 & 45.45 & 1 & 9.090 & 5 & 45.45 \\
\hline S14 & 4 & 36.36 & 2 & 18.18 & 5 & 45.45 \\
\hline S15 & 5 & 45.45 & 2 & 18.18 & 4 & 36.36 \\
\hline S16 & 2 & 18.18 & 5 & 45.45 & 4 & 36.36 \\
\hline S17 & 4 & 36.36 & 5 & 45.45 & 2 & 18.18 \\
\hline S18 & 6 & 54.54 & 4 & 36.36 & 1 & 9.090 \\
\hline S19 & 2 & 18.18 & 7 & 63.63 & 2 & 18.18 \\
\hline S20 & 3 & 27.27 & 1 & 9.090 & 7 & 63.63 \\
\hline S21 & 2 & 18.18 & 4 & 36.36 & 5 & 45.45 \\
\hline S22 & 6 & 54.54 & 0 & & 5 & 45.45 \\
\hline S23 & 2 & 18.18 & 3 & 27.27 & 6 & 54.54 \\
\hline
\end{tabular}

\begin{tabular}{|c|r|r|r|r|r|r|}
\hline $\begin{array}{c}\text { Stu- } \\
\text { dent }\end{array}$ & \multicolumn{2}{|c|}{ Misconception } & \multicolumn{2}{c|}{$\begin{array}{c}\text { Concept } \\
\text { Ignorance }\end{array}$} & \multicolumn{2}{c|}{$\begin{array}{c}\text { Understand the } \\
\text { concept }\end{array}$} \\
\cline { 2 - 7 } & $\begin{array}{c}\text { Total } \\
\text { number }\end{array}$ & \% & $\begin{array}{c}\text { Total } \\
\text { number }\end{array}$ & \% & $\begin{array}{c}\text { Total } \\
\text { number }\end{array}$ & $\%$ \\
\hline S24 & 1 & 9.09 & 5 & 45.45 & 5 & 45.45 \\
\hline
\end{tabular}

From the data in Table II, there were 9 students who already understand about chemistry concepts. Only 2 students who get misconception profile with more than $50 \%$ from total number of questions. There were 3 students in concepts ignorance profile because they achieve more than $50 \%$ from total number of questions.

The sample of students has different of ability and gender. They also already enroll theses course that is mean they already gain more than 100 semester credit system. In the university they enrolled basic chemistry, organic chemistry, inorganic chemistry, physical chemistry, analytic chemistry, and biochemistry. From the course they enrolled, it is a big hope that they have knowledge to be transferred when they teach the real class.

Based on the data in Table II it is also showed that the highest number of questions correctly answered by students is 6. It is only $54.54 \%$ from 11 questions. It also showed that none of the students mastery the chemistry topics. While there were 1 to 6 questions that showed students' misconception about 8 chemistry topics. It is a big problem faced by the lecturer/educator. How can the curriculum help the students understand chemistry concepts in all chemistry topics enrolled in the college? This is a classic problem that always occurred every year with different students and different/same educators.

Based on the course they enrolled, there were 8 topics tested for 24 students to figure out students' competencies in chemistry. Each topic represented by 1 question except reaction rate, thermodynamic, and organic chemistry that represented by 2 questions. The total percentage of students who get misconception, concept ignorance, and understand the concept profiles showed in Table III.

Based on data in Table III, the highest percentage in misconception is redox reaction topic, while in concept ignorance is acid base. The highest percentage of student who understands the concept is atomic model.

TABLE III THE PERCENTAGE OF STUDENTS FOR THREE PROFILES OF EACH TOPIC

\begin{tabular}{|c|c|c|c|}
\hline \multirow{2}{*}{ Topics } & \multicolumn{3}{|c|}{ Percentage of students } \\
\cline { 2 - 4 } & $\begin{array}{c}\text { Misconcep- } \\
\text { tion }\end{array}$ & $\begin{array}{c}\text { Concept } \\
\text { Ignorance }\end{array}$ & $\begin{array}{c}\text { Under- } \\
\text { stand the } \\
\text { Concept }\end{array}$ \\
\hline Stoichiometry & 62.50 & 29.17 & 8.40 \\
\hline Atomic model & 20.83 & 16.67 & 62.50 \\
\hline Thermodynamic & 35.42 & 20.83 & 43.75 \\
\hline Reaction rate & 12.50 & 37.50 & 50.00 \\
\hline Chemistry Equilibrium & 12.50 & 66,67 & 20.83 \\
\hline Redox reaction & 62.50 & 8.33 & 29.17 \\
\hline Acid base & 16.67 & 58.33 & 25.00 \\
\hline Organic chemistry & 14.58 & 35.42 & 50.00 \\
\hline
\end{tabular}


On the topic of stoichiometry there are difficulties faced by students in answering questions about limiting reactants. In this problem students did not use the mole principle as the main concept in stoichiometric calculations. When students calculate mol iodine they do not count Mr to 258 but only divide the mass by Ar from iodine. This is the cause of the high misconceptions, seen in Table III. Previous study also found that students difficulties in having the conceptual understanding of the problem, namely, being able to translate the worded problems into a suitable chemical and mathematical equation, and using the correct formula to calculate the mole, before they able to solve the problem [5].

Acid base topic has the highest percentage of concept ignorance. This is because in acid base students could not give reason why they choose the answer option and they were not sure their answer. It also showed that students did not use variety way to strengthen their answer. This finding is not in line with previous study by Cooper, which Cooper found that students use a variety of ways to reason about acid-base reactions that can be characterized using a framework which allows responses to be classified according to the model used and whether the students invoke a causal explanation [6]. The reason is because students were not forced to have correct answer. There was nothing to be achieved when they did the problem set.

In the problem that represents the acid-base topic, the problem presented is about the buffer solution. The reason students said when answering this question showed that they did not calculate the concentration of residual acid so that the results were lower than the correct calculation. In addition, the answers of other students showed their inability to use the buffer solution formula.

Atomic model has the highest percentage for students who achieve understanding of concept. The question is about the theory of atomic model. The students give reason why they choose the option by comparing to other theories. It showed that they already comprehend in understand of atomic model. Although atomic model is an abstract concept but the student can imagine by using analogy. The analogy of Rutherford atomic model is mosquito coils. The model use can make the students easy to imagine the concept of atomic model. This study also in line with previous study by Sarikaya, Sarikaya found that the value that modeling was quite useful in the teaching of science, and that students' misconceptions could be remedied through the use of models [7].

In senior high school the student already has their own knowledge that they achieve from textbook, teacher, students' discussion. As noted by Sarikaya that science educators have particularly focused their research on the concepts that students in pre-university education have about atoms and molecules, in the context of the particulate nature of matter [7]. For the last 40 or 45 years, the results of studies had shown that students of all ages held misconceptions about basic science concepts such as stoichiometry and atomic model, regardless of where they were on the earth [7].

\section{CONCLUSION AND SUGGESTION}

\subsection{Conclusion}

Based on the findings that there are 2 out of 24 students having a misconception rate of more than $50 \%$ and there are 5 out of 24 students who know the concept, it showed how important the curriculum. The lecturer can not only use traditional method to transfer the information to students. As an educator, the determination of the misconceptions is very important in terms of choosing teaching methodologies and tools that fits with student's character as well as preparing an effective curriculum [8]. One of several work of educator is to teach the truth and to remedy misconceptions immediately, which the students have [7].

\subsection{Suggestion}

Student learning is an active process. The students must aware what they study, how the study, and why they have to study it- and what students do with facts and ideas with which they have been presented depends to a very high degree on what they already think and believe [9]. When the students already maintain the false concept, it will be difficult to transfer the correct concept. Educator can uses conceptual change oriented instruction because it seemed to decrease the percentages of misconceptions [10]. Teacher or lecturer must understand the model and technique to make the students easy to understand the topic discussed. Thomson consider that science can be considered to be a sequential process, so can the development of misconceptions so that once a misconception has been acquired it may be carried on and built upon further, again and again [11]. This is a big challenge for educator to diagnose what concept that 'fragile' to be accepted in misconception by students.

\section{REFERENCES}

[1] B. Birgili. "Creative and critical thinking skills in problem-based learning environments". Journal of Gifted Education and Creativity. 2(2), pp 71-80, December2015

[2] B. Yonata and H. Nasrudin, "Laboratory activity worksheet to train high order thinking skill of student on surface chemistry lecture" IOP Conf. Series: Journal of Physics: Conf. Series 947 (2017) 012027 doi :10.1088/1742-6596/947/1/012027.

[3] I.N. Sari and B. Yonata. "Students' questioning and opinion skills on chemistry bonds in X-mia class 4 kemala bhayangkari 1 surabaya high school through application of cooperative learning model with question student have (QSH) strategy' -Keterampilan bertanya dan berpendapat siswa pada materi ikatan kimia di kelas X-mia 4 sma kemala bhayangkari 1 surabaya melalui penerapan model pembelajaran kooperatif dengan strategi question student have (QSH)-. UNESA Journal of Chemical Education ISSN: 2252-9454 Vol. 1. No. 1. pp. 84-89. January 2015.

[4] L. Mathelitsch, "Competencies in science teaching" - In: CEPS Journal, S. 49-64 - URN: urn:nbn:de:0111-opus-82628, March 2013

[5] K. Sujak and E.G.S. Daniel. "Understanding of macroscopic, microscopic and symbolic representations among form four students in solving stoichiometric problems", Malaysian Online Journal of Educational Sciences (Volume5 - Issue 3) p. 83-96. 2017

[6] M.M. Cooper, H Kouyoumdjian, and S.M. Underwood, "Investigating students' reasoning about acid-base reactions", DOI: 10.1021/acs.jchemed.6b00417 J. Chem. Educ. 2016, 93, 1703-1712. 2016

[7] M. Sarikaya, "Prospective teachers' misconceptions about the atomic structure in the context of electrification by friction and an activity in 
order to remedy them", International Education Journal, 8(1), 40-63. ISSN 1443-1475 @Shannon Research Press, 2007.

[8] N. Seçkena, "Identifying student's misconceptions about SALT. Procedia Social and Behavioral Sciences 2", 234-245. doi:10.1016/j.sbspro.2010.03.004. 2010

[9] C. Horton, "Student alternative conceptions in chemistry (originally: student misconceptions and preconceptions in chemistry)", 2014
[10] E. Taşlidere, "Effect of conceptual change oriented instruction on students' conceptual understanding and decreasing their misconceptions in DC electric circuits", Creative Education 2013. Vol.4, No.4, 273-282 Published Online April 2013 in SciRes DOI:10.4236/ce.2013.44041.

[11] F. Thompson and S. Logue, "An exploration of common student misconceptions in science", International Education Journal, 7(4), 553559. ISSN 1443-1475 @Shannon Research Press. 2006 